\title{
EFFECT OF ROW SPACING AND SOWING RATE ON SEED YIELD OF ALFALFA (Medicago sativa L.) UNDER MEDITERRANEAN CONDITIONS
}

\author{
Mustafa AVCI ${ }^{1}$, Rustu HATIPOGLU², Selahattin CINAR ${ }^{3 *}$, Celal YUCEL ${ }^{4}$, Ilker INAL ${ }^{4}$ \\ ${ }^{1}$ Omer Halisdemir University, Faculty of Agricultural Sciences and Technologies, Department of Plant \\ Production and Technologies, Nigde, TURKEY \\ ${ }^{2}$ Cukurova University, Faculty of Agriculture, Department of Field Crops, Adana, TURKEY \\ ${ }^{3}$ Kilis 7 Aralik University, Vocational School, Kilis, TURKEY \\ ${ }^{4}$ East Mediterranean Agricultural Research Institute, Adana, TURKEY \\ ${ }^{*}$ Corresponding author: scinar01@hotmail.com
}

Received: 02.05.2016

\begin{abstract}
The effects of row spacing $(25,50,75$ and $100 \mathrm{~cm})$ and sowing rate $\left(4,8\right.$ and $\left.12 \mathrm{~kg} \mathrm{ha}^{-1}\right)$ on alfalfa (Medicago sativa L.) seed yield and its components were investigated under Mediterranean conditions throughout the years of 2008-2011. In the study cultivar Nimet was used and it was evaluated for number of pods per raceme, number of seeds per pod, biomass yield, harvest index, thousand seed weight and seed yield.

The results of the study indicated that row spacing and sowing rate significantly affected biomass yield and harvest index but no significant differences were found in pod number and thousand seed weight. Seed yield was significantly affected by sowing rate. The highest and the lowest seed yield were recorded in the first and third years of the experiment, respectively. The highest seed yield averaged over three years was obtained from $25 \mathrm{~cm}$ row spacing with $4 \mathrm{~kg} \mathrm{ha}^{-1}$ seed rate while the lowest one was obtained from $75 \mathrm{~cm}$ row spacing with combining $4 \mathrm{~kg} \mathrm{ha}^{-1}$ seed rate. Results of this study suggest that among the various row spacing and seeding rates, narrower row spacings $(25 \mathrm{~cm}$ or $50 \mathrm{~cm})$ with the lowest seeding rate $\left(4 \mathrm{~kg} \mathrm{ha}^{-1}\right)$ were found to be better treatments for alfalfa seed production under Cukurova ecological conditions.
\end{abstract}

Key words: Alfalfa, row spacing, sowing rates, seed yield components

\section{INTRODUCTION}

Seed yield of alfalfa (Medicago sativa L.) is important in determining the effective distribution of new cultivars to farmers (Bolanos-Aguilar et al., 2002). Many genetic and environmental factors affect seed yield. Successful alfalfa seed production is favored in regions that are characterized by clear, sunny, warm summer days in combination with little or no rainfall. These climatic conditions promote good flowering of alfalfa and provide an environment conductive to the pollinating activity of bees. In addition to a favorable climate, there are other variables that will influence the yield and quality of alfalfa seed. Stand density is known to be an important factor in seed production because competition between and within plants affects a plant's ability to produce vegetative and reproductive material. The flowering period should be timed to coincide with the period of least competition from other pollen sources and greatest pollinator activity. The best period of flowering is not the same for every location because seed is grown over a wide range of climatic conditions where different pollinators predominate. Irrigation requirement for alfalfa seed production is dependent upon soil texture, natural precipitation, temperature, and length of growing season. Highest seed yield could be obtained when irrigation practices prevent severe plant stress and promote slow, continuous growth through entire production period without excessive stimulation of vegetative growth.

According to Rincker et al. (1988), seed yield is a complex trait and it depends on the number of seeds per unit area and individual seed weight. Seeds are produced in pods and the yield components include number of seeds per pod, number of pods per raceme, number of stems per plant and number of plants per unit area. They also stated that alfalfa seed yields range from 0 (crop failures) to a verified yield of $2110 \mathrm{~kg} \mathrm{ha}^{-1}$ of clean seed. Thin, uncrowded stands are recognized capable of producing higher seed yield than dense stands in solid planted fields. Low seed production from dense stands can be explained in part by low nectar production, unattractiveness to pollinators, and increased floral abortion. Proper row spacing for alfalfa depends on soil depth and texture, total water availability, length of growing season, cultivar and possibly other factors.

In the previous researches, carried out in different countries, (Askarian et al., 1995; Mermer and Serin, 2007; 
Abadouz et al., 2010) various and often not consistent suggestions were stated about appropriate row spacing and seeding rate to achieve the highest seed yield of alfalfa. According to Askarian (1993), recommendations for optimum row spacing and sowing rate for alfalfa seed production vary in the literature, and several studies have reported conflicting results. He also stated that in New Zealand, alfalfa seed has commonly been produced in rows 9 or $18 \mathrm{~cm}$ apart at sowing rates of $6-12 \mathrm{~kg} \mathrm{ha}^{-1}$. Along with that in the United States, row spacings from 60 to $150 \mathrm{~cm}$ apart and seed rates from 0.5 up to $2 \mathrm{~kg} \mathrm{ha}^{-1}$ were reported (Abu Shakra et al. 1969).

The increase in the production of alfalfa seed yield should help to provide sufficient supply of local alfalfa seed, which would decrease the dependence on imported seed. Objectives of this study were to determine the optimum row spacing and seeding rate for alfalfa cultivar Nimet and its seed production potential under Cukurova climatic conditions.

\section{MATERIALS AND METHODS}

Non-dormant (Fall dormancy rating 8) synthetic cultivar Nimet was used as plant material for field experiment at the East Mediterranean Agricultural Research Institute, Adana, Turkey $\left(36^{\circ} 51.675 \mathrm{~N}, 035^{\circ}\right.$ $20.662 \mathrm{E}$, altitude $14 \mathrm{~m}$ above sea level) under irrigated management conditions during 2008-2011. The soil type was silty-clay; with organic matter content $2.51 \%$, pH level 7.62, and $\mathrm{P}_{2} \mathrm{O}_{5}$ level $87.0 \mathrm{~kg} \mathrm{ha}^{-1}$ and rich in lime. The southern region of Turkey has long growing season and moderate climatic conditions during winter. Summers are hot and humid with many days above $30^{\circ} \mathrm{C}$. Meteorological data of location is presented in Table 1. The mean long-term annual temperature is $18.8{ }^{\circ} \mathrm{C}$, the lowest and highest average temperatures occur in January and August, respectively. During the experiment years annual average temperatures were 19.1, 20.7 and 18.8, respectively. Annual average temperature was lower in 2011 comparison to 2009 and 2010.

Table 1. Some meteorological data of Adana province

\begin{tabular}{|c|c|c|c|c|c|c|c|c|c|c|c|c|}
\hline \multirow[b]{2}{*}{ Months } & \multicolumn{4}{|c|}{ Average temperature $\left({ }^{\circ} \mathrm{C}\right)$} & \multicolumn{4}{|c|}{ Total precipitation (mm) } & \multicolumn{4}{|c|}{ Relative humudity (\%) } \\
\hline & 2009 & 2010 & 2011 & LYA & 2009 & 2010 & 2011 & LYA & 2009 & 2010 & 2011 & LYA \\
\hline Jauary & 10.0 & 11.0 & 9.9 & 9.3 & 146 & 148 & 79 & 109 & 63.1 & 68.6 & 64.1 & 65.6 \\
\hline February & 11.0 & 12.0 & 11.2 & 10.0 & 131 & 80 & 113 & 84 & 73.6 & 63.4 & 62.5 & 63.7 \\
\hline March & 13.0 & 14.8 & 13.2 & 13.0 & 135 & 0 & 83 & 60 & 66.5 & 62.0 & 66.5 & 65.1 \\
\hline April & 18.0 & 17.5 & 16.5 & 17.3 & 34 & 40 & 117 & 48 & 63.5 & 62.9 & 68.5 & 67.1 \\
\hline May & 22.0 & 21.1 & 20.2 & 21.5 & 29 & 0 & 30 & 44 & 58.5 & 66.2 & 69.3 & 66.0 \\
\hline June & 27.0 & 25.0 & 24.5 & 25.3 & 0 & 1.4 & 0 & 21 & 59.8 & 64.9 & 72.1 & 67.0 \\
\hline July & 28.0 & 27.8 & 27.9 & 27.8 & 23 & 0.7 & 0 & 10 & 66.1 & 67.4 & 72.7 & 70.7 \\
\hline August & 29.0 & 30.2 & 28.8 & 28.3 & 0 & 0 & 0 & 8 & 59.2 & 64.0 & 67.6 & 70.8 \\
\hline September & 25.0 & 27.2 & 26.9 & 26.0 & 33 & 1.7 & 0 & 15 & 60.7 & 66.6 & 63.4 & 64.4 \\
\hline October & 24.0 & 21.6 & 20.8 & 21.3 & 16 & 17 & 6 & 52 & 57.9 & 63.4 & 49.4 & 60.8 \\
\hline November & 15.0 & 19.1 & 12.6 & 14.7 & 130 & 0 & 35 & 85 & 69.3 & 53.3 & 54.5 & 64.0 \\
\hline December & 12.0 & 13.3 & 10.0 & 10.6 & 131 & 212 & 225 & 120 & 72.1 & 71.5 & 65.5 & 66.7 \\
\hline Mean/Total & 19.1 & 20.7 & 18.8 & 18.8 & 808 & 501 & 661 & 655 & 64.2 & 64.5 & 65.5 & 66.0 \\
\hline
\end{tabular}

Long-term averaged annual precipitation of the Province Adana is $655 \mathrm{~mm}$, most of rain falls in winter months so distribution unbalanced and leading to long and short-term droughts in summer months, while relative humidity of the province is $66.0 \%$. Throughout the research years of 2009, 2010 and 2011, total annual precipitation amounts were calculated as 808, 501 and $661 \mathrm{~mm}$ respectively. In the third year of the experiment monthly average relative humidity, especially for June, was calculated to be relatively higher than those in 2009 and 2010 (Anonymous, 2009-2011).

The seedbed was prepared by ploughing and then firming with a field cultivator and harrow. The experiment was arranged in a split-plot design with four replications. Main plots were row spacings and the sub-plots were sowing rates. The area of each sub-plot was $3 \mathrm{~m} \times 5 \mathrm{~m}=$ $15 \mathrm{~m}^{2}$. The row spacings were $25,50,75$ and $100 \mathrm{~cm}$, and the sowing rates were 4,8 and $12 \mathrm{~kg} \mathrm{ha}^{-1}$. Plots were fertilized with $120 \mathrm{~kg} \mathrm{ha}^{-1}$ of $\mathrm{P}_{2} \mathrm{O}_{5}$ and $50 \mathrm{~kg} \mathrm{ha}^{-1}$ of $\mathrm{N}$ prior to sowing. The plots were sown on 20 March 2008.
The first year of study (2008) was considered as establishment year and plots were harvested several times for hay production. In the second, third and fourth years of study, first harvests were done at the first week of May when plants reached to the early flowering stage $(\underline{10 \%}$ bloom). Second harvests were made for seed production. Normally in the Cukurova basin (deep-medium or heavytextured soils) winter and early spring rains could satisfy requirements of alfalfa for second-crop seed production unless rainy season is not drought. However enough moisture must be supplied in the spring and especially summer months to maintain growth and overcome the detrimental effects of moisture stress. Therefore flood irrigation was applied when it was needed. The weather in March, April and May of 2010 had lower precipitation (0.0, 40.0 and $0.0 \mathrm{~mm})$ in comparison to the same months of 2009 and 2011 (135, 34, 29 and 83,117, $30 \mathrm{~mm}$ respectively), (Table 1). For that reason, one irrigation was made after first cutting for hay production only in the spring of 2010. Two irrigations in August and in September after seed harvest were done in all three years. 
Weeds were controlled with hand hoeing as needed throughout the growing seasons. Pollination during the seed production years was provided primarily by leaf cutter bees (Megachile rotundata) naturally found in the region (Avci et al. 2010b), and other pollinators such as honey bees (Apis mellifera L.) and bumble bees (Bombus spp.). Although honey bees were in high populations, their tripping activities were lower than those of leaf cutter bees. To determine the number of pods per raceme and the number of seeds per pod 20 racemes were chosen randomly in each plot (Dordas, 2006). After counting the pods on a one raceme, they were grinded by hand and the average number of seeds per pod was calculated. Forage dry biomass, harvest index and seed yields were estimated by harvesting the center of each plot $(8,4,3$ and 2 rows with a $4 \mathrm{~m}$ length for $25,50,75$ and $100 \mathrm{~cm}$ row spacings, respectively). Plots were harvested when the most of the pods were reached to black-browned color (Askarian et al. 1995) during the second week of July. All harvested plant material from each plot was air dried for each year and weighed to determine alfalfa dry biomass.
The harvest index was calculated as the ratio between seed yield and total alfalfa dry biomass (seed + seed pods + all vegetative parts). To obtain clean seed, naturally dried plant material from each plot was threshed and cleaned by experimental sieves and blower. Seed yield was determined weighing harvested seed from each plot.

Analysis of variance was performed using the MSTAT-C statistical analysis programmer, and differences were compared using Duncan's multiple range test (Steel and Torrie, 1960).

\section{RESULTS AND DISCUSSION}

\section{Pod number}

Results of the variance analysis showed that the number of pods per raceme was not significantly influenced by row spacing and sowing rate in 2009, 2011 and three years average (Table 2).

Table 2. Averaged values for the number of pods per raceme under three sowing rates and four row-spacings in the years of 2009 , 2010 and 2011

\begin{tabular}{|c|c|c|c|c|c|}
\hline \multirow{2}{*}{ Row spacing (cm) } & \multirow{2}{*}{ Sowing rate $\left(\mathrm{kg} \mathrm{ha}^{-1}\right)$} & \multicolumn{4}{|c|}{ Years } \\
\hline & & 2009 & 2010 & 2011 & Average \\
\hline \multirow{3}{*}{25} & 4 & 18.1 & 14.0 & 11.7 & 14.6 \\
\hline & 8 & 17.2 & 13.8 & 11.4 & 14.1 \\
\hline & 12 & 17.6 & 13.7 & 11.6 & 14.3 \\
\hline \multirow[t]{2}{*}{ Mean } & & 17.6 & $13.8 \mathrm{~B}+$ & 11.5 & 14.3 \\
\hline & 4 & 17.5 & 14.5 & 11.8 & 14.6 \\
\hline \multirow[t]{2}{*}{50} & 8 & 18.3 & 14.9 & 12.3 & 15.2 \\
\hline & 12 & 17.0 & 14.9 & 12.0 & 14.7 \\
\hline \multirow[t]{2}{*}{ Mean } & & 17.6 & $14.8 \mathrm{~A}$ & 12.0 & 14.8 \\
\hline & 4 & 16.9 & 13.2 & 11.4 & 13.8 \\
\hline \multirow[t]{2}{*}{75} & 8 & 17.0 & 14.3 & 11.9 & 14.4 \\
\hline & 12 & 17.1 & 14.1 & 11.7 & 14.3 \\
\hline \multirow{2}{*}{ Mean } & & 17.0 & 13.9 B & 11.7 & 14.2 \\
\hline & 4 & 18.2 & 14.8 & 11.5 & 14.8 \\
\hline \multirow{2}{*}{100} & 8 & 18.6 & 14.9 & 11.9 & 15.1 \\
\hline & 12 & 17.5 & 14.1 & 11.4 & 14.3 \\
\hline Mean & & 18.1 & $14.6 \mathrm{AB}$ & 11.6 & 14.8 \\
\hline Grand Mean & & $17.6 \mathrm{~A}^{*}$ & $14.3 \mathrm{~B}$ & $11.7 \mathrm{C}$ & 14.5 \\
\hline
\end{tabular}

Although no significant differences were found among treatments, the highest mean number of pods (18.1) per raceme was found in $100-\mathrm{cm}$ row spacing in the first year of experiment (2009). In contrast, the averaged values in 2010 were influenced by row spacing. The number of pods per raceme tended to increase as row spacing increased from $25 \mathrm{~cm}$ to $50 \mathrm{~cm}$ and it was significantly higher at the $50 \mathrm{~cm}$ than those at $25 \mathrm{~cm}$ and $75 \mathrm{~cm}$. Significant differences were observed among years for number of pods per raceme. Averaged pod number per raceme (17.6) in 2009 was significantly higher than those in 2010 and 2011 (Table 2). Although the effect of row spacing on the number of pods per raceme was significant in 2010, no consistent trend was detected among the three years averaged values of pod number per raceme. Alfalfa has a highly specialized flower with a unique tripping mechanism that limits the types of insects providing pollination. The percentage of flowers setting pods in a highly self-sterile plant may vary considerably, depending partly upon the environment. Plant density and plant vigor usually decline with increasing stand age (Sheaffer et al. 1988; Avci et al. 2010a; Cinar and Hatipoglu, 2015). Decreasing the number of pods per raceme as years advanced can be attributed to the reductions in plant vigor and for this reason to reductions in biomass production, flowers and number of pods per raceme. In the previous researches, Askarian et al. (1995), Zhang et al. (2008), Rashidi et al. (2009) and Abadouz et al. (2010) found similar results to our findings that sowing rate and row spacing had not significant effect on pod number per raceme. 


\section{Seed number}

Row spacing and sowing rate did not significantly affect seed number per pod during the experimental years (Table 3). However, the highest (5.48) and the lowest (4.63) number of seeds per pod were determined with the combination of $25-\mathrm{cm}$ row spacing and $8 \mathrm{~kg} \mathrm{ha}^{-1}$ sowing rate, and with that of $100 \mathrm{~cm}$ row spacing and $4 \mathrm{~kg} / \mathrm{ha}$ sowing rate, respectively, in 2009, whereas the highest seed numbers per pod were recorded with $75 \mathrm{~cm}$ row spacing and $12 \mathrm{~kg}$ ha sowing rate in 2010 and 2011.

Table 3. Averaged values for seed number per pod under three sowing rates and four row-spacings in the years of 2009, 2010 and 2011

\begin{tabular}{|c|c|c|c|c|c|}
\hline \multirow{2}{*}{ Row spacing (cm) } & \multirow{2}{*}{ Sowing rate $\left(\mathrm{kg} \mathrm{ha}^{-1}\right)$} & \multicolumn{4}{|c|}{ Years } \\
\hline & & 2009 & 2010 & 2011 & Average \\
\hline \multirow{3}{*}{25} & 4 & 4.80 & 4.87 & 4.85 & 4.84 \\
\hline & 8 & 5.48 & 4.50 & 4.28 & 4.75 \\
\hline & 12 & 5.03 & 4.05 & 4.03 & 4.37 \\
\hline \multirow[t]{2}{*}{ Mean } & & 5.01 & 4.47 & 4.39 & 4.65 \\
\hline & 4 & 4.85 & 4.69 & 4.45 & 4.66 \\
\hline \multirow{2}{*}{50} & 8 & 5.13 & 5.02 & 4.76 & 4.97 \\
\hline & 12 & 5.32 & 4.64 & 4.38 & 4.78 \\
\hline \multirow[t]{2}{*}{ Mean } & & 5.10 & 4.78 & 4.53 & 4.80 \\
\hline & 4 & 4.91 & 4.71 & 4.56 & 4.69 \\
\hline \multirow[t]{2}{*}{75} & 8 & 4.86 & 4.89 & 4.63 & 4.79 \\
\hline & 12 & 5.19 & 5.28 & 5.01 & 5.16 \\
\hline \multirow{2}{*}{ Mean } & & 4.99 & 4.96 & 4.70 & 4.88 \\
\hline & 4 & 4.63 & 4.85 & 4.65 & 4.71 \\
\hline \multirow[t]{2}{*}{100} & 8 & 5.14 & 4.90 & 4.70 & 4.91 \\
\hline & 12 & 5.34 & 5.05 & 4.77 & 5.05 \\
\hline Mean & & 5.04 & 4.93 & 4.70 & 4.89 \\
\hline Grand Mean & & $5.07 A^{*}$ & 4.79 B & $4.85 \mathrm{C}$ & 4.81 \\
\hline
\end{tabular}

The year effect (environmental conditions during growing season) was significant for seed number per pod. The mean number of seeds per pod in the first experimental year was significantly higher than those in the second and third years, and it was significantly higher in the second year than that in the third year (Table 3). The high percentage of flower abortion occurs in lucerne and seed number per pod is closely related with the amount of the production and storage of photosynthetic materials (Gender et al., 1997).

The poor performance of mean seed number per pod, like pod number per raceme, in 2010 and 2011 can be attributed to competition among plants for nutrients, senescence, disease and other pest's damages. Based on average of three years, the seed number per pod changed between 4.37 and 5.16, but no statistically significant differences were found among them. According to Wang et al. (2011) an alfalfa flower has 7-13 ovules, but only a small proportion usually develop into seed. They also stated that the numbers of ovules per ovary, fertile ovules per floret and the number of seeds per pod among the alfalfa varieties varied. Few-to-many ovules can be sterile and unavailable for fertilization (Rosellini et al. 1998). A low seed/ovule ratio is a general characteristic of outcrossing species. In general, no more than 5 ovules per pod could become seed (Lorenzetti, 1993). In the previous researches, Rashidi et al. (2009) reported the number of seed per pod as 5.5-5.7, Gender et al. (1997) as 3.36-4.62, Iannucci et al. (2002) as 1.04-7.41, Abdouz et al. (2010) as 4.1-4.8 and Dordas (2006) as 1.85-9.16. According to the results of this study, the number of seeds per pod wasa unimportant yield component at different plant densities. This results agree with those of Askarian et al., (1995) and Zhang et al. (2008), who reported that there were no change in the number of seeds per pod when plants were grown at different row spacings.

\section{Biomass yield}

The statistical results of the study indicated that biomass yield (dry weights of shoots and seeds) was significantly $(\mathrm{P} \leq 0.05)$ influenced by the row spacing in 2009 and both row spacing and sowing rates in the averaged values of three years (Table 4 ). 
Table 4. Averaged values $\left(\mathrm{kg} \mathrm{ha}^{-1}\right)$ for biomass yield under three sowing rates and four row-spacings in the years of 20092010 and 2011

\begin{tabular}{|c|c|c|c|c|c|}
\hline \multirow{2}{*}{ Row spacing (cm) } & \multirow{2}{*}{ Sowing rate $\left(\mathrm{kg} \mathrm{ha}^{-1}\right)$} & \multicolumn{4}{|c|}{ Years } \\
\hline & & 2009 & 2010 & 2011 & Average \\
\hline \multirow{3}{*}{25} & 4 & 6158 & 4263 & 4240 & 4887 \\
\hline & 8 & 6200 & 4345 & 3995 & 4846 \\
\hline & 12 & 6270 & 4583 & 4318 & 5057 \\
\hline \multirow[t]{2}{*}{ Mean } & & $6209 \mathrm{~A}+$ & 4397 & 4184 & $4930 \mathrm{~A}+$ \\
\hline & 4 & 5228 & 4250 & 4065 & 4514 \\
\hline \multirow[t]{2}{*}{50} & 8 & 5118 & 4025 & 3765 & 4303 \\
\hline & 12 & 5283 & 4225 & 3870 & 4459 \\
\hline Mean & & 5209 B & 4167 & 3900 & $4425 \mathrm{AB}$ \\
\hline \multirow{3}{*}{75} & 4 & 4718 & 3712 & 3530 & 3987 \\
\hline & 8 & 5000 & 3810 & 3673 & 4161 \\
\hline & 12 & 5040 & 4320 & 4155 & 4505 \\
\hline \multirow[t]{2}{*}{ Mean } & & 4919 B & 3948 & 3786 & 4218 B \\
\hline & 4 & 4423 & 3240 & 3478 & 3713 \\
\hline \multirow[t]{2}{*}{100} & 8 & 4847 & 3598 & 3760 & 4065 \\
\hline & 12 & 4733 & 3568 & 3915 & 4072 \\
\hline \multirow[t]{2}{*}{ Mean } & & $4664 \mathrm{~B}$ & 3468 & 3718 & 3950 B \\
\hline & 4 & 5131 & 3866 & 3828 & $4275 \mathrm{~B}+$ \\
\hline \multirow{2}{*}{ A.V.S.R } & 8 & 5289 & 3944 & 3798 & $4344 \mathrm{~B}$ \\
\hline & 12 & 5331 & 4174 & 4064 & $4523 \mathrm{~A}$ \\
\hline Grand Mean & & $5250 \mathrm{~A}^{*}$ & 3995 B & 3897 B & 4381 \\
\hline
\end{tabular}

There were also significant year effect and year $\mathrm{x}$ sowing rate interactions on biomass production. Sowing rates did not have statistically significant effect on dry biomass production in the all years.

In the first year of the research, the narrowest $(25 \mathrm{~cm})$ row spacing produced statistically significant higher biomass yield than the other row spacings tested. Increasing row spacing resulted in decreasing the biomass yield, but the biomass yields at wider row spacing than 25 $\mathrm{cm}$ were not statistically different from each other. In the second and third years of the research, the biomass yield was not statistically significant influenced by the row spacing. According to the averaged values over three years, row spacing of $25 \mathrm{~cm}$ resulted in statistically significant higher biomass yield than the row spacings of 75 and $100 \mathrm{~cm}$. The row spacing of $50 \mathrm{~cm}$ gave statistically smilar biomass yield with all other row spacings. On the other hand, increasing sowing rate increased the biomass yiled and the biomass yield at $12 \mathrm{~kg}$ $\mathrm{ha}^{-1}$ was significantly higher than those at the sowing rates of 4 and $8 \mathrm{~kg} \mathrm{ha}^{-1}$. Plants were smaller and less vigorous in 2010 and 2011 as compared in the second year of establishment (2009). Therefore averaged biomass yield $\left(5250 \mathrm{~kg} \mathrm{ha}^{-1}\right)$ in the second year of establishment was higher than those (3995 and $3897 \mathrm{~kg} \mathrm{ha}^{-1}$, respectively) in the other years. The climatic conditions, especially during the vegetative growth, were quite variable. The year 2009 with higher and steadily rainfall up to the June was the best year for alfalfa biomass production when compared with 2010 and 2011. Lower rainfall during the vegetative growth period could explain the lower dry biomass yield obtained in 2010. During the vegetative growth period in 2011, the amount of the precipitation was higher than in the year of 2010, but increasing the stand age and declining the plant vigor resulted in significant biomass yield decrease. Bolanos-Aguilar et al. (2002) reported that seed yield of alfalfa cultivars was highly correlated with aboveground biomass at harvest $(\mathrm{r}=0.94)$. In another study (Gender et al. 1997) stated that seed production of lucerne is very low (250- $400 \mathrm{~kg} \mathrm{ha}^{-1}$ seed) compared to its high vegetative biomass $\left(8000 \mathrm{~kg} \mathrm{ha}^{-1}\right)$.

\section{Harvest index}

Results of the variance analysis showed that the harvest index of alfalfa was significantly influenced by row spacing and sowing rate and their interactions (AXB) in the first year (Table 5). But it was influenced by only row spacing in the second and third years of the experiment. Based on averaged values over three years, row spacing, sowing rate, and year significantly affected the harvest index. On the other hand, significant interactions were determined between row spacing and years $(\mathrm{AxC})$, and among the row spacing, sowing rates and years $(\mathrm{AxBxC})$ 
Table 5. Averaged values (\%) for harvest index under three sowing rates and four row-spacings in the years of 2009,2010 and 2011

\begin{tabular}{|c|c|c|c|c|c|}
\hline \multirow{2}{*}{ Row spacing (cm) } & \multirow{2}{*}{ Sowing rate $\left(\mathrm{kg} \mathrm{ha}^{-1}\right)$} & \multicolumn{4}{|c|}{ Years } \\
\hline & & 2009 & 2010 & 2011 & Average \\
\hline \multirow{3}{*}{25} & 4 & $14.6 \mathrm{bc}^{1}$ & 14.2 & 7.53 & 12.1 \\
\hline & 8 & $10.6 \mathrm{f}-\mathrm{h}$ & 14.6 & 7.65 & 10.9 \\
\hline & 12 & $9.6 \mathrm{~h}$ & 13.6 & 7.85 & 10.4 \\
\hline \multirow[t]{2}{*}{ Mean } & & $11.6 \mathrm{~B}+$ & $14.1 \mathrm{~B}+$ & $7.68 B+$ & 11.1B+ \\
\hline & 4 & $13.3 \mathrm{c}-\mathrm{e}$ & 16.1 & 9.05 & 12.8 \\
\hline \multirow[t]{2}{*}{50} & 8 & $14.1 b-d$ & 15.6 & 8.30 & 12.7 \\
\hline & 12 & $10.4 \mathrm{gh}$ & 16.1 & 10.6 & 12.4 \\
\hline \multirow[t]{2}{*}{ Mean } & & $12.6 \mathrm{~B}$ & 15.9 AB & 9.33AB & 12.6A \\
\hline & 4 & $12.4 d-f$ & 16.2 & 11.4 & 13.3 \\
\hline \multirow[t]{2}{*}{75} & 8 & $12.7 \mathrm{c}-\mathrm{e}$ & 17.6 & 10.9 & 13.7 \\
\hline & 12 & $11.6 \mathrm{e}-\mathrm{g}$ & 17.0 & 9.78 & 12.8 \\
\hline \multirow[t]{2}{*}{ Mean } & & $12.2 \mathrm{~B}$ & $16.9 \mathrm{~A}$ & 10.7A & 13.3A \\
\hline & 4 & $16.9 \mathrm{a}$ & 17.7 & 9.08 & 14.5 \\
\hline \multirow[t]{2}{*}{100} & 8 & $14.2 b-d$ & 16.0 & 8.70 & 12.9 \\
\hline & 12 & $15.7 \mathrm{ab}$ & 16.1 & 8.48 & 13.4 \\
\hline \multirow[t]{2}{*}{ Mean } & & $15.6 \mathrm{~A}$ & $16.6 \mathrm{~A}$ & 8.75 B & $13.6 \mathrm{~A}$ \\
\hline & 4 & $14.3 \mathrm{a}^{1}$ & 16.1 & 9.3 & $13.2 \mathrm{~A}+$ \\
\hline \multirow[t]{2}{*}{ A.V.S.R } & 8 & $12.9 \mathrm{~b}$ & 16.0 & 8.9 & $12.6 \mathrm{~B}$ \\
\hline & 12 & $11.8 \mathrm{c}$ & 15.7 & 9.2 & $12.2 \mathrm{~B}$ \\
\hline Grand Mean & & 13.0B* & $15.9 \mathrm{~A}$ & $9.11 \mathrm{C}$ & 12.7 \\
\hline
\end{tabular}

In the first year of the experiment, the highest harvest index values were recorded at $100 \mathrm{~cm}$ row spacing and 4 $\mathrm{kg} \mathrm{ha}^{-1}$ sowing rates while the lowest ones were found in the narrowest row spacing with $12 \mathrm{~kg} \mathrm{ha}^{-1}$ sowing rate. The lower harvest index from the combination of $25 \mathrm{~cm}$ row spacing and $12 \mathrm{~kg}$ ha sowing rate suggesting that the thicker plant density produced much more biomass but it could not compensate seed and pod development. High density of bushes on rows has undesirable effect on production seed rate (Abadouz, 2010). In the second and third years of the experiment, increasing the row spacing up to $75 \mathrm{~cm}$ increased harvest index and this row spacing resulted in statistically significant higher harvest index than that at the row spacing of $25 \mathrm{~cm}$. Increasing the row spacing more than $75 \mathrm{~cm}$ did not increase the harvest index as compared with that at $75 \mathrm{~cm}$ row spacing. Based on averaged values over three years, the row spacing of 50 $\mathrm{cm}$ gave statistically significant higher harvest index than the row spacing of $25 \mathrm{~cm}$ but it was statistically similar with the row spacings of 75 and $100 \mathrm{~cm}$. Harvest index is an important indicator of how vegetative mass is allocated to seed at crop maturity (Iannucci, 2002; Dordas, 2006).

According to the three year averaged values, the sowing rate of $4 \mathrm{~kg} \mathrm{ha}^{-1}$ gave statistically significant higher harvest index than the other sowing rates, and increasing sowing rate decreased the harvest index (Table $5)$.

Averaged harvest index $(15.9 \%)$ in the second year was significantly higher than those of the first and third years $(13.0$ and $9.11 \%)$. Alfalfa is a primarily crosspollinated species, and a flower must be tripped before fertilization, so it must be visited at least once by an insect for seed setting. During the flowering and pollination periods in the third year of experiment, average relative humidity of June $(72.1 \%)$ was significantly higher than those of the first and second years (Table 1). Higher humidity during the flowering period under hot temperature conditions of Cukurova basin had a negatively impact on pollination activity of the pollinator bees, and this could be reason of the lower harvest index in the year of 2011 .

The results on the harvest index from this study are in agreement with those of Iannucci et al. (2002), who stated that the weather conditions affected the harvest index and seed yield. They also stated that wide range of harvest index values ( 4.2 to 24.2 ) had been determined in alfalfa however no consistent relationship was found between treatments and cultivars in that character over the 3 -year period.

Harvest index values determined in the present study were higher than those reported by Askarian (1993); Mermer and Serin (2007), while they are similar with those reported by Bolanos-Aguilar et al. (2002).

\section{0-seed weight}

The 1000-seed weight was not statistically significan influenced by the varying row spacing and sowing rate in 2009, 2010, and 2011 and in the averaged values over three years. Averaged value of 1000 -seed weight was statistically significant higher in the first year than those in the second and third years of experiment (Table 6). 
Table 6. Averaged values (g) for 1000 seed weight under three sowing rates and four row-spacings in the years of 2009,2010 and 2011

\begin{tabular}{|c|c|c|c|c|c|}
\hline \multirow{2}{*}{ Row spacing (cm) } & \multirow{2}{*}{ Sowing rate $\left(\mathrm{kg} \mathrm{ha}^{-1}\right)$} & \multicolumn{4}{|c|}{ Years } \\
\hline & & 2009 & 2010 & 2011 & Average \\
\hline \multirow{3}{*}{25} & 4 & 2.08 & 1.90 & 1.84 & 1.94 \\
\hline & 8 & 2.07 & 1.84 & 1.82 & 1.91 \\
\hline & 12 & 2.06 & 1.90 & 1.85 & 1.94 \\
\hline \multirow[t]{2}{*}{ Mean } & & 2.07 & 1.88 & 1.84 & 1.93 \\
\hline & 4 & 2.10 & 1.88 & 1.84 & 1.94 \\
\hline \multirow[t]{2}{*}{50} & 8 & 2.11 & 1.87 & 1.86 & 1.94 \\
\hline & 12 & 2.07 & 1.89 & 1.84 & 1.93 \\
\hline \multirow[t]{2}{*}{ Mean } & & 2.09 & 1.88 & 1.85 & 1.94 \\
\hline & 4 & 2.05 & 1.84 & 1.80 & 1.89 \\
\hline \multirow[t]{2}{*}{75} & 8 & 2.05 & 1.92 & 1.83 & 1.93 \\
\hline & 12 & 2.06 & 1.93 & 1.82 & 1.93 \\
\hline \multirow[t]{2}{*}{ Mean } & & 2.05 & 1.90 & 1.82 & 1.92 \\
\hline & 4 & 2.15 & 1.93 & 1.87 & 1.98 \\
\hline \multirow[t]{2}{*}{100} & 8 & 2.04 & 1.87 & 1.82 & 1.91 \\
\hline & 12 & 2.06 & 1.89 & 1.83 & 1.92 \\
\hline Mean & & 2.08 & 1.90 & 1.84 & 1.94 \\
\hline Grand Mean & & $2.07 \mathrm{~A}^{*}$ & $1.89 \mathrm{~B}$ & $1.83 \mathrm{C}$ & 1.93 \\
\hline
\end{tabular}

According to the averaged values over three years, the lowest sowing rate $\left(4 \mathrm{~kg} \mathrm{ha}^{-1}\right)$ with the widest row spacing $(100 \mathrm{~cm})$ produced the highest 1000 -seed weight $(1.98 \mathrm{~g})$, while the lowest 1000 -seed weight $(1.89 \mathrm{~g})$ was determined at the $4 \mathrm{~kg} \mathrm{ha}^{-1}$ sowing rate and $75 \mathrm{~cm}$ row spacing. However no statistically significant differences found among them.

These results supported the finding of Zhang et al. (2008) who reported that seed size was influenced primarily by years but no significant differences betweenrow spacing treatments over the years. Rashidi et al. (2009) also stated that seeding rates did not significantly affect the 1000- seed weight. In the previous researches, 1000- seed weight of alfalfa was found by Askarian (1993) as 1.53-1.82 g; by Mermer and Serin (2007) as $1.86-1.95 \mathrm{~g}$; by Wang et al. (2011) as $1.63-2.07 \mathrm{~g}$; Iannucci et al. (2002) as 1.92-2.32 g; by Dordas (2006) as $1.74-2.39 \mathrm{~g}$; by Rashidi et al. (2009) as 2.24-2.29 g. The values related to 1000 seed weight recorded in this study were lower than those reported by Rashidi et al. (2009) and higher than those Askarian et al. (1995) while 1000 seed weight values determined by Mermer and Serin (2007) were similar with those of this study. These results indicate that environmental conditions and cultivar differences (Rincker et al. 1988; Iannucci et al. 2002; Zhang et al. 2008) have greatly effect on 1000-seed weight.

\section{Seed yield}

Results of the variance analysis showed that the seed yield of alfalfa was significantly influenced by sowing rates in the first and second years. In addition to these, row spacing $\mathrm{x}$ sowing rate $(\mathrm{AxB})$ interactions in the first and second years and in the averaged values over three years were found highly significant. Seed yield did not significantly change depending on the row spacing during the years of the experiment.

Based on combined analyses of the data from three years, row spacing $\mathrm{x}$ sowing rate $(\mathrm{AXB})$, year $(\mathrm{C})$, row spacing $\mathrm{x}$ year $(\mathrm{AxC})$, and sowing rate $\mathrm{x}$ year $(\mathrm{BxC})$ interactions significantly affected the seed yield (Table 7).

In the first year of experiment the highest seed yield (834 $\mathrm{kg} \mathrm{ha}^{-1}$ ) was obtained from the narrowest row spacing at the $4 \mathrm{~kg} \mathrm{ha}^{-1}$ seed rate, while the lowest yield $\left(582 \mathrm{~kg} \mathrm{ha}^{-1}\right)$ was obtained from $50 \mathrm{~cm}$ row spacing at the rate of $12 \mathrm{~kg} \mathrm{ha}^{-1}$ seed (Table 7). In this year, increasing the sowing rate decreased the mean seed yield, and the lowest sowing rate $\left(4 \mathrm{~kg} \mathrm{ha}^{-1}\right)$ produced statistically significant higher seed yield (754 versus 707 and $667 \mathrm{~kg}$ $\mathrm{ha}^{-1}$ ) than two higher sowing rates. On the other hand, mean seed yield at the sowing rate of $8 \mathrm{~kg} \mathrm{ha}^{-1}$ was statistically significant higher than that at the sowing rate of $12 \mathrm{~kg} \mathrm{ha}^{-1}$. However the highest sowing rate $\left(12 \mathrm{~kg} \mathrm{ha}^{-}\right.$ ${ }^{1}$ ) produced statistically significant higher mean seed yield than the other sowing rates in the the second year. In the third year, increasing the sowing rate tended to increase the mean seed yield, but these increases were not statistically significant. (Table (7). In the first year higher sowing rates probably create greater interplant competition, resulting in a negative effect on seed yield. In the next two years, the lowest seed yields were consistently obtained from the lower seed rates probably that with the thinner or spaced plant density could no longer compensate for declining seed yield. 
Table 7 Averaged values $\left(\mathrm{kg} \mathrm{ha}^{-1}\right)$ for seed yield under three sowing rates and four row-spacings s in 2009, 2010 and 2011

\begin{tabular}{|c|c|c|c|c|c|}
\hline \multirow{2}{*}{ Row spacing (cm) } & \multirow{2}{*}{ Sowing rate $\left(\mathrm{kg} \mathrm{ha}^{-1}\right)$} & \multicolumn{4}{|c|}{ Years } \\
\hline & & 2009 & 2010 & 2011 & Average \\
\hline \multirow{3}{*}{25} & 4 & $834 \mathrm{a}^{1}$ & $610 a-c^{1}$ & 335 & $593 \mathrm{a}^{1}$ \\
\hline & 8 & $676 \mathrm{~b}-\mathrm{e}$ & $619 a-c$ & 354 & $550 \mathrm{a}-\mathrm{d}$ \\
\hline & 12 & $672 \mathrm{~b}-\mathrm{e}$ & $631 \mathrm{a}-\mathrm{c}$ & 400 & $568 \mathrm{a}-\mathrm{d}$ \\
\hline \multirow[t]{2}{*}{ Mean } & & 727 & 620 & 363 & 570 \\
\hline & 4 & 738 a-d & $645 \mathrm{ab}$ & 386 & $590 \mathrm{ab}$ \\
\hline \multirow[t]{2}{*}{50} & 8 & 694 b-d & $563 \mathrm{~cd}$ & 352 & $536 \mathrm{~b}-\mathrm{d}$ \\
\hline & 12 & $582 \mathrm{e}$ & $653 \mathrm{a}$ & 409 & 548 a-d \\
\hline \multirow[t]{2}{*}{ Mean } & & 671 & 620 & 382 & 558 \\
\hline & 4 & $666 \mathrm{c}-\mathrm{e}$ & $524 \mathrm{~d}$ & 351 & $514 \mathrm{~d}$ \\
\hline \multirow[t]{2}{*}{75} & 8 & $754 \mathrm{a}-\mathrm{d}$ & $591 \mathrm{a}-\mathrm{d}$ & 388 & $577 \mathrm{a}-\mathrm{c}$ \\
\hline & 12 & $646 \mathrm{de}$ & $649 a b$ & 403 & 566 a-d \\
\hline \multirow{2}{*}{ Mean } & & 689 & 588 & 381 & 552 \\
\hline & 4 & $779 \mathrm{ab}$ & $533 d$ & 311 & $541 \mathrm{a}-\mathrm{d}$ \\
\hline \multirow[t]{2}{*}{100} & 8 & $703 b-d$ & $570 \mathrm{~cd}$ & 318 & $530 \mathrm{~cd}$ \\
\hline & 12 & $769 a-c$ & $579 b-d$ & 329 & 559 a-d \\
\hline \multirow[t]{2}{*}{ Mean } & & 750 & 561 & 319 & 543 \\
\hline & 4 & $754 a^{1}$ & $578 b^{1}$ & 346 & 560 \\
\hline \multirow[t]{2}{*}{ A.V.S.R } & 8 & $707 \mathrm{~b}$ & $586 b$ & 353 & 548 \\
\hline & 12 & $667 \mathrm{c}$ & $628 \mathrm{a}$ & 385 & 560 \\
\hline Grand Mean & & $709 A^{*}$ & 597 B & $361 \mathrm{C}$ & 556 \\
\hline
\end{tabular}

This results probably indicate that wide row spacing promotes more branches, flowers per plant, higher percentage seed set, and higher seed yield per plant (Kowithayakorn and Hill, 1982). However, the combination of narrower row spacing with higher sowing rates consistently had higher seed yield as year advanced.

The highest and the lowest seed yields were determined in the first and third years respectively. The poor performance of alfalfa in 2010 and 2011 can be attributed to stand decline with competition among plants, senescence, diseases and other pest damages. Because plant population and yield (herbage and seed yield) usually decline with increasing stand age (Sheaffer et al. 1988). Avci et al. (2007) also found that alfalfa cultivars produced the highest seed yield in the second years of establishment. Reductions in plant vigorous result in decreasing biomass production, flowers and number of pods per racemes. In the previous researches, seed yield of alfalfa was found by Askarian et al. (1993) as 102-209 kg $\mathrm{ha}^{-1}$; by Iannucci et al. (2002) as $130-660 \mathrm{~kg} \mathrm{ha}^{-1}$; by Rashidi et al. (2009) as 606-805 kg ha-1; by Avci et al. (2007) as 537-634 $\mathrm{kg} \mathrm{ha}^{-1}$. The mean values related to seed yields recorded in this study (543-570 $\mathrm{kg} \mathrm{ha}^{-1}$ ) were lower than those reported by Rashidi et al. (2009), higher than those Askarian et al. (1995), while similar Avci et al. (2007). Variation among the yields may be due to differences in location, climatic conditions and management techniques under researches were conducted.

\section{CONCLUSIONS}

Results of this study suggest that among the various row spacing and seeding rates, narrower row spacings (25 $\mathrm{cm}$ or $50 \mathrm{~cm})$ with the lowest seeding rate $\left(4 \mathrm{~kg} \mathrm{ha}^{-1}\right)$ were found to be better treatments for alfalfa seed production under Cukurova ecological conditions.

\section{LITERATURE CITED}

Abadouz, G., A., H. Gorttapeh, A. A. Rahnema and A. Behradfar. 2010. Effect of row spacing and seeding rate on yield component and seed yield of alfalfa (Medicago sativa L.). Notulae Scientia Biologicae, 2 (1), 74-80.

Anonymous, 2009. Meteorological data for Adana.http://www.wunderground.com.

Anonymous, 2010. Meteorological data for Adana.http://www.wunderground.com.

Anonymous, 2011. Meteorological data for Adana.http://www.wunderground.com.

Abu Shakra, S., M. Akhar and D.W. Bray. (1969). Infulence of irrigation interval and plant density on alfalfa seed production. Agronomy Journal. 61:562-571.

Askarian, M. 1993. Seed Production Studies in Lucerne (Medicago sativa L.) cv. Grassland Oranga. PhD Thesis Massey Univ. New Zeland.

Askarian, M., J.G. Hampton and M.J.Hill. 1995. Effect of row spacing and sowing rate on seed production of lucerne (Medicago sativa L.) cv. Grassland Oranga. New Zeland J.of Agrc. Research. 38:289-295.

Avci, M., S. Kizil., S. Cinar., R. Hatipoglu., C.Yucel, I. Inal, H. Yucel, R. Gultekin and A. Aktas. 2007. A study on the effects of row spacing on seed yield of Alfalfa (Medicago sativa L.) under Cukurova conditions. VII. National Field Crops Congress. Erzurum, Turkey. p.75-78.

Avci, M., S.Cinar., C.Yucel., and I. Inal. 2010a. Evaluation of some selected alfalfa (Medicago sativa L.) lines for herbage yield and forage quality. Journal of Food Agriculture and Environment Vol. 8, Issue 3\&4, pages 545-449.

Avci, M., R. Hatipoglu, H. Yucel, R. Gultekin. 2010b. Effect of Pollinator bees on pod and seed setting of Alfalfa (Medicago 
sativa L.) clones. The Journal of the Faculty of Veterinary Medicine Univ. of Kafkas. 16 (Supp B):S305-311.

Bolanos-Aguilar,E.D., C., Huyghe, C., Ecalle, J.,Hacqet, and B., Julier. 2002. Effect of Cultivar and Environment on Seed Yield in Alfalfa. Crop Sci.42:45-50.

Cinar, S., and R. Hatipoglu. 2015. Quality characteristics of the mixtures of some warm season perennial grasses with Alfalfa (Medicago sativa L.) under irrigated conditions of Cukurova. Turkish Journal of Field Crops 20(1) 31-37.

Dordas, C. 2006. Foliar Boron Application Improves Seed Set, Seed Yield and Seed Quality of Alfalfa. Agronomy Journal 98:907-913.

Gender, T., E. Deleens and A. Fleury. 1997. Infulence of photosynthetic restiriction due to defoliation at fowering on seed abortion in lucerne (Medicago sativa L). J.Exp. Bot. 48:1815-1823.

Kowithayakorn, L., and M.J.Hill. 1982. A study of seed production of Lucerne under different plant spacing and cutting treatments in the sowing year. Seed Sci.Technology $10: 3-12$.

Iannucci, A., N. Di Fonzo, P. Martiniello. 2002. Alfalfa (Medicago sativa L.) seed yield and quality under different forage management systems and irrigation treatments in a Mediterranean environment. Field Crops Research 78: 6574.

Lorenzetti F. 1993. Achieving potential herbage seed yield in species of temperate regions. In: Proceedings of the XVII International Grassland Congress, 15-16 February, Lincoln, New Zealand, pp: 1621-1628.
Mermer, A. and Y. Serin. 2007. The effects of seeding rates and row distances on seed production of an alfalfa (Medicago sativa L.) variety (Bilensoy). VII. National Field Crops Congress. Erzurum, Turkey. p.281-284.

Rashidi ,M., B. Zand, and M. Gholami. 2009. International J. of Agriculture \& Biology.,11:779-782.

Rincker, C.M., V.L. Marble., D.E. Brown and C.A. Johansen. 1988. Seed Production Practices. In Hanson, A. A. et al. (eds). Alfalfa and Alfalfa Improvement. Agron., ASA, CSSA, and SSSA, Madison 32:985-1021.

Rosellini F., E. Lorenzetti, T. Bingham. 1998. Quantitative ovule sterility in Medicago sativa Theor. Appl. Genet. (1998) 97: 1289-1295

Sheaffer, C. C., G.D. Lacefield., and V.L. Marble. 1988. Cutting Schedules and Stands In Hanson, A. A. et al. (eds). Alfalfa and Alfalfa Improvement. Agron., ASA, CSSA, and SSSA, Madison 29:411-437.

Steel, R.G.D. and J.H.Torrie. 1960. Principles and Procedures of Statistics With Special Reference to the Biological Sciences. Mc Graw-Hill Book Co., Inc., London.

Wang X.J., X.Li., J. Zhang., G. Feng., S. Zhang., L.Huang., R.J.Zhuo. 2011. Characterization of nine alfalfa varieties for differences in ovule numbers and ovule sterility. Australian Journal of Crop Science AJCS 5(4):447-452.

Zhang, T., X.Wang., J. Han., Y.Wang., P. Mao., and M. Majerus. 2008. Effects of Between-Row and Within-Row Spacing on Alfalfa Seed Yields. Crop Science, Vol. 48:794803. 